\title{
Tariff and Non-tariff Barriers to Trade in Korea
}

\author{
Michael Daly and Sergios Stamnas \\ World Trade Organization
}

\begin{abstract}
Since the conclusion of the Uruguay Round (UR) negotiations, Korea has taken steps to reduce, if not remove, tariff and non-tariff barriers (NTBS) to trade as well as to encourage inward foreign direct investment, notwithstanding the Asian financial crisis that erupted in 1997. In the wake of the crisis, Korea has continued to pursue major reforms. Nonetheless, the customs tariff is the principal instrument of Korea's trade policy. It accords substantial and highly varied levels of protection at the border to domestic industry and is therefore a potentially important obstacle to the efficient allocation of resources and therefore sustained growth. The average applied most-favoured-nation (MFN) tariff is higher than in most other industrialised countries. Moreover, tariff "spikes" are pervasive, particularly as far as agricultural products are concerned; this is partly due to the "tariffication" of agricultural NTBs in accordance with the UR. Korea also uses several types of NTBs. Estimates of some relatively simple summary and complementary indicators for tariffs are reported in this paper; they are designed to reflect the level and structure of tariffs. In addition, some non-tariff barriers to trade are discussed briefly.
\end{abstract}

JEL Classifications: F14, H29

Key words: Trade, Tariff

*Corresponding address: Michael Daly and Sergios Stamnas, Tel:+44-22-739-5077, Fax:+41-22-7395765, Email: michael.daly@,wto.org

Sergios Stamnas, Tel:+41-22-739-5382,Fax:+41-22-739-5765, Email: sergios.stamnas@wto.org 


\section{INTRODUCTION}

Since the conclusion of the Uruguay Round (UR) of multilateral trade negotiations, Korea has taken steps to reduce, if not remove, tariff and non-tariff barriers (NTBs) to trade as well as to encourage inward foreign direct investment, notwithstanding the Asian financial crisis that erupted in 1997. Korea has continued to pursue major reforms not only in accordance with its WTO (and crisis-related IMF) commitments, but also in response to concerns raised by some of its trading partners. These reforms also reflect plurilateral arrangements, including those reached in APEC and OECD fora. While Korea has, by and large, resisted protectionist pressures, maintaining instead an outward-oriented trade and investment regime, WTO Members, for their part, have kept their markets open to Korea's exports, thereby helping to set the stage for a remarkable recovery of the Korean economy from the crisis.

The outcome is that real GDP, which shrank by $6.7 \%$ in 1998 as a result of the crisis, rebounded to grow by $10.7 \%$ in 1999 . Inflation, after jumping from $4.5 \%$ in 1997 to $7.5 \%$ in 1998 , dropped to $0.8 \%$ in 1999 . The unemployment rate peaked at $8.6 \%$ in February 1999 , more than three times its pre-crisis level; but as a result of the recovery of production activities, it dropped to $4.8 \%$ at the end of 1999. Market-based reforms, including the liberalisation of its international trade and foreign investment regime, have not only fostered Korea's economic recovery, but also reduced its vulnerability to external shocks and established a solid basis for sustainable growth in the future.

Despite steps to liberalise its international trade, the customs tariff remains the main instrument of Korea's trade policy It accords substantial and highly varied levels of protection at the border to domestic production and is therefore a potentially important obstacle to the efficient allocation of resources. The average applied most-favoured-nation (MFN) tariff is higher than in most other OECD countries. Moreover, tariff "spikes" are pervasive, particularly as far as agricultural products are concerned; this is partly due to the "tariffication" of agricultural NTBs in accordance with the UR. The tariff is also an important source of tax revenue, accounting for $6.5 \%$ of total tax revenues in 1999; indeed, among OECD countries, Korea is one of the most heavily dependent on tariffs for revenues.

Like other countries, Korea also uses several types of NTBs, notably import prohibitions, quantitative restrictions, tax measures, state-trading operations, government procurement practices, standards requirements and contingency measures (namely countervailing and anti-dumping duties as well as safeguards); many of these NTBs are aimed at imports of certain sensitive items (mainly agricultural and fish products). The Government's toleration of anti-competitive practices by large domestic conglomerates (chaebols) and state-owned enterprises may also constitute a barrier to trade. 
The rest of this paper is organised as follows. In view of the tariff's importance as an instrument of Korea's trade policy, some relatively simple summary and complementary tariff indicators are described in the next section; they are designed to reflect the level and structure of tariffs. The existence of tariff "spikes" in certain sectors constitutes prima facie evidence that the domestic deadweight efficiency and net welfare losses caused by tariff protection as well as the costs to consumers could be high. ${ }^{1}$ Estimates of tariff indicators for Korea are reported in Section III; these estimates are derived from a data base constructed by the WTO. ${ }^{2}$ Some non-tariff barriers to trade are also discussed briefly. The final section contains some concluding remarks including a caveat.

\section{METHODOLOGY CONCERNING TARIFF INDICATORS}

The structure of Korea's customs tariff is relatively complex. The general schedule for 2000 consisted of 11,169 tariff lines (at the ten-digit HS level), 2.8\% more than in 1996, and a multiplicity of duties involving 125 different rates (96 ad valorem rates levied on the c.i.f. value of imports, 11 specific and 18 alternate rates) ${ }^{3}$; however, about $61 \%$ of tariff lines (mostly those pertaining to industrial goods) are set at a rate of $8 \%$. In order to enhance the transparency of the Korean tariff schedule, attention is focused on a few summary indicators that capture the key features of its existing tariff structure and help to identify those groups of products for which the potential distortions in consumption and production patterns are likely to be greatest. There are a number of important conceptual issues related to the construction of summary tariff indicators, notable among which are: (a) the appropriate tariff rate; (b) the weights, if any, used for aggregation purposes; and (c) the appropriate indicators of dispersion in tariff rates.

\section{(a) Tariff rate}

A clear distinction should be made between the nominal (or statutory) tariff rate and the collected tariff rate. The latter is the amount of customs duties as a proportion of the value of a given group of imported products. It thus reflects the average transfer to the government from domestic consumers of the products subject to duty. However, the collected tariff rate does not necessarily bear any relation to the "marginal" tariff rate, which is the most appropriate indicator of the potential dead-weight (efficiency) losses caused by duties. In particular, it ignores prohibitive tariffs that do

\footnotetext{
${ }^{1}$ Dead-weight losses to consumers and producers are only one of a number of channels through which trade restrictions may affect net economic welfare. Other channels include gains or losses from rent shifting between countries, losses associated with rent-seeking activities, possible gains from improved terms of trade, gains or losses in scale economies, changes in product variety, and reduced diffusion of technology.

${ }^{2}$ This data base includes measures affecting imports, not those affecting exports.

${ }^{3}$ Whereas ad valorem duties are calculated as a constant proportion of the value-for-duty of the imported good, specific duties are expressed as a fixed monetary amount per physical unit or per unit of weight of the product imported, so that the associated degree of protection (or implicit assistance) is not independent of
} 
not yield any revenues at all. As a consequence, collected tariff rates are not usually regarded as reliable indicators of the potentially distorting effects of the tariff structure on domestic resource allocation.

The simplest and most straight forward nominal tariff rate to use is the applied MFN rate. The latter should be distinguished from the bound MFN rate, which is usually the highest rate of applied duty permissible under a country's schedule of commitments at the WTO. ${ }^{4}$ (GATT/WTO tariff negotiations involve primarily the binding of tariff rates and reductions therein.) Not all tariffs are bound, so that in some instances bound rates do not exist. The applied MFN rate, in contrast to the collected tariff rate, excludes preferential rates and exemptions. The greater the use of preferences and exemptions, the greater the difference between the applied MFN rate, or average, and the collected rate. The nominal MFN rates actually applied may be viewed as an indicator of the maximum nominal degree of tariff protection against imports originating in WTO Members. If imports of a particular tariff item from all sources are perfect substitutes for each other, however, the existence of significant amounts of imports subject to the MFN rate constitutes evidence that this particular rate may in fact be the relevant marginal rate for the purpose of analysing the potentially distorting effects of those tariffs that are actually applied. The granting of preferential rates tends merely to compensate those suppliers for their cost disadvantage, and does not result in trade creation (that is, increased imports from all suppliers). In such a situation, the provision of preferential rates or exemptions is purely trade diverting because it changes the composition of a country's imports from different sources without affecting the total volume of imports. ${ }^{5}$ The tariff-inclusive prices of imports from all sources would be the same, that is, the MFN-inclusive price. ${ }^{6}$ Thus, the tariff averages reported in Section III are based largely on nominal applied MFN rates.

In contrast to the nominal tariff rate, the effective tariff rate focuses on value added and takes into account tariffs levied on imported inputs (allowing for industry-specific tariff concessions). Insofar as domestic industry uses inputs that are subject to duty, the nominal tariff rate applied to imports of a particular commodity is not an indicator of the effective rate of protection. The extent to which value added is protected is a more accurate indicator of the potential distortion in domestic resource allocation. Unfortunately, indicators involving effective tariff rates require much more data than those based on nominal rates.

the import price and can therefore change independently of the tariff rate. Alternate duties involve either specific or ad valorem rates, whichever is greater.

${ }^{4}$ Bound tariffs can be exceeded, but only in special circumstances. These circumstances are specified in Article XXVIII of the GATT.

${ }^{5}$ The emphasis on MFN rates is consistent with the emphasis on the domestic impact of tariff protection. Preferential rates are relevant for the determination of the impact of tariffs on bilateral trade flows and thus in evaluating the effects of tariffs on global trade patterns and resource allocation. 
As regards the choice of weighting method for purposes of computing nominal tariff averages, there are problems with all available schemes. Averages can vary considerably depending on the weights used. The main drawback of the simple (unweighted) arithmetic average of the tariff rates is that it takes no account of the relative importance of various products.

Among the main alternatives to simple averages are the shares of imports or of domestic production. ${ }^{7}$ The use of actual import volumes assigns a small weight to the highly-protected products, however, thus tending to underestimate the degree of protection. ${ }^{8}$ Furthermore, the use of variable-import weights can result in spurious movements in weighted averages over time as the weights themselves would tend to be inversely related to a country's tariff rates. By contrast, although the use of actual domestic production weights over-represents highly-protected products, it avoids the spurious movements often associated with variable-import weights.

As none of the viable weighting methods is free from drawbacks, with each method giving rise to some aggregation bias, both simple (unweighted) and constant import-share-weighted averages are reported in this paper. The latter involved the composition/shares of overall import values for the OECD (of which Korea is a Member) in 1998. ${ }^{9}$ Needless to say, it is unlikely that the composition of Korean imports in the absence of tariffs (or NTBs) would resemble the average for the OECD (which also reflects trade distortions). Moreover, while use of OECD import weights to some extent avoids the downward bias inherent in countries' "own" import weights, some bias remains insofar as the levels and structure of their tariffs are similar. Thus, even weighted tariff averages based on overall OECD imports need to be interpreted cautiously.

Interestingly, both simple and import-share-weighted averages have been used in relation to GATT/WTO negotiations. Import-weighted averages are used by the GATT/WTO as an indicator of progress in achieving MFN tariff reductions. By contrast, commitments to reduce agricultural tariffs

${ }^{6}$ On the other hand, if the country subject to the preferential rate can fully satisfy the demand for the imported item, then the preferential rate rather than the MFN rate would be the marginal rate.

7 The ideal weights to use in calculating import-weighted or production weighted averages are obviously the values of imports or production in the absence of barriers. Unfortunately, these values are unobservable. If one is interested in effective rates of protection, weights should be based on domestic value-added rather than domestic production weights.

${ }^{8}$ No weight at all is given to prohibitive tariffs.

${ }^{9}$ In fact, OECD import weights are available only at the 6-digit level (or higher) of the Harmonized System (HS). As a consequence, tariff rates are aggregated in the form of simple averages from the national tariff line (10-digit level, for example) to the common 6-digit level. Thus, OECD import-weighted tariff averages at the 6-digit level and above are in fact hybrids of simple and import-weighted averages. 
following the "tariffication" exercise agreed in the UR are measured in terms of simple averages (presumably on simplicity grounds and also because some tariffs may have been prohibitive). ${ }^{10}$

\section{(c) Dispersion index}

The dead-weight losses associated with Korea's tariff structure depend not just on average tariff rates, but on the variation in these rates across products. The higher the dispersion in tariff rates, particularly within groups of similar and, thus, highly substitutable products, the greater the likelihood that consumers' and producers' decisions are distorted by the tariff structure. ${ }^{11}$ The dispersion also provides an indication of the complexity of the tariff schedule as well as the potential inequities it embodies as far as consumers are concerned. ${ }^{12}$

Among the most commonly used indicators of dispersion are the standard deviation (SD) and the coefficient of variation (CV), both of which are related to each other. The SD is a statistical measure of the absolute dispersion between items in a frequency distribution. The CV measures relative dispersion by dividing the SD by the average tariff rate. SDs and CVs can be computed not just for all products, but also for various groups and sub-groups of products. If products within a given group face widely different tariff rates, this can result in large changes in their relative prices. ${ }^{13}$ Large changes in relative prices constitute a potentially serious source of distortion to domestic consumption and production patterns. Relatively high risk groups of products may be considered to be those for which the $\mathrm{SD}$ or $\mathrm{CV}$ is especially large. What matters for resource allocation, however, are the tariff-inclusive prices of imported products and thus the absolute magnitudes of tariffs as well as differences therein. This suggests that, from the resource allocation standpoint, the SD is a more appropriate indicator of potential economic distortion than the $\mathrm{CV}$.

An additional indicator of dispersion is the number (or proportion) of items for which the tariff rate exceeds a reference level. ${ }^{14}$ The reference level may, for example, be a specified multiple of the overall domestic average tariff rate. Tariff rates in excess of the given domestic reference level are referred to as domestic "spikes". The "spikier" a country's tariff schedule, the greater the potentially

${ }^{10}$ Interestingly, as required by the GATT/WTO, recent adjustments in the EU tariff in order to compensate non-Member countries for the accession of Austria, Finland, and Sweden were based on "collected" tariff averages for various groups of products.

${ }^{11}$ Strictly speaking, a uniform nominal tariff (or a uniformly restrictive NTB) minimises the net welfare cost of such protection only if import demand elasticities are uniform across commodities and cross-price effects are negligible. Tariff uniformity may be desirable on administrative simplicity and political grounds, however. For a discussion of these and related matters, see Panagariya and Rodrik (1993).

${ }_{12}$ Moreover, the larger the dispersion in tariff rates applicable to various products, the greater the incentive for exporters and importers to reclassify products so that they are subject to lower tariffs.

${ }^{13}$ Imperfectly competitive pricing (or rising marginal costs under perfect competition) may mean that the domestic price does not increase by the full amount of the tariff, in which case, there will be a gain in the terms of trade for the importing country.

${ }^{14}$ Another indicator of dispersion is the tariff range. 
distorting effects on competition and trade, particularly if such "spikes" are found alongside much lower rates for similar (highly substitutable) products.

In the light of the foregoing considerations concerning the choice of the nominal tariff rate, weighting schemes and dispersion indices, the main features of Korea's customs tariff are captured by the following 12 indicators:

1) the percentage of all (including "in-quota" and "out-of-quota") tariff lines that are "bound";

2) the percentage of tariff lines for which the applied MFN tariff rate is zero;

3) non-ad valorem (namely specific) and alternate tariffs as a percentage of all tariffs;

4) tariff quotas as a percentage of all tariffs;

5) tariffs for which no ad valorem equivalents (AVEs) were available as a percentage of tariff lines;

6) the simple average of "bound" MFN tariff rates ${ }^{15}$;

7) the simple average of "applied" ad valorem MFN tariff rates;

8) the import-weighted average MFN tariff rate (using 1998 OECD-wide import weights);

9) the number of domestic tariff "spikes" as a percentage of tariff lines, where a domestic "spike" is defined as an applied MFN tariff rate that exceeds three times the simple average (indicator 7) for all products;

10) the number of international tariff "spikes" as a percentage of tariff lines, where a international "spike" is defined as an applied MFN tariff rate that exceeds $15 \%$;

11) the standard deviation (SD) of applied MFN tariff rates; and

12) the coefficient of variation (CV) of applied MFN tariff rates.

Indicator 1) shows the proportion of tariff lines for which MFN tariff rates are "bound". Indicator 2) captures the proportion of tariff lines that are not subject to duty. Indicators 3), 4) and 5), highlight the presence of relatively opaque non-ad valorem tariffs and tariff quotas. Indicator 6) shows the highest permissible level of nominal MFN tariff protection consistent with the rates bound under the GATT/WTO. By contrast, indicators 7), and 8) reflect actual nominal levels of MFN tariff protection. Indicators 9) to 12) capture the domestic dispersion in applied MFN tariff rates across products.

${ }^{15}$ The simple average is defined as the sum of tariff rates applicable to a given group of tariff lines divided by the number of tariff lines in the group. 
Overall magnitudes of the above indicators for the Korea in 1996, 2000, 2004 and under full implementation of the UR and Information Technology Agreement (ITA) are reported in Table $1 .^{16}$

\section{PRINCIPAL FINDINGS}

\section{Tariffs}

(a) MFN tariff bindings

As a consequence of the Uruguay Round, Korea bound virtually all (99\%) agricultural tariff lines ${ }^{17}$, while expanding considerably its bindings (from about $10 \%$ to $92.8 \%$ of tariff lines) for industrial products. The outcome is that currently $91.7 \%$ of all Korea's tariff lines are bound, compared to $90.4 \%$ in 1996 . The reason for not binding the remaining of industrial tariff lines is presumably to maintain the Government's freedom to provide flexible border protection to either ailing or infant industries. $^{18}$

The simple average bound tariff rate has fallen from $27.6 \%$ in 1996 to $20.1 \%$ in 2000 , and is to drop further to about $17 \%$ by 2004 , thereby substantially narrowing the gap between bound and applied rates (see below). The fall in average bound rate levels can be attributed, inter alia, to changes with respect to motor vehicles (namely a cut in the bound rate from $80 \%$ to $8 \%$ as of 11 March 1999) together with telecommunications and information related equipment (zero rate by the year 2000, except for certain items); these changes resulted from the 1998 automotive negotiations with the United States (but were extended to other WTO Members on an MFN basis) and the 1996 WTO Ministerial Declaration on Trade in Information and Technology (ITA). ${ }^{19}$ Prohibitive binding levels (ad valorem and alternate rates) ranging from $100.5 \%$ to $887.4 \%$ (manioc), affect more than 100 agricultural and livestock items owing to the "tariffication" exercise.

${ }^{16}$ For agricultural items, UR reductions in bound tariffs are being implemented in equal annual instalments over the period 1995-2004; for other items, implementation may take from 5 to 15 years (as in the case of tariff harmonisation of chemical products) depending on the base rate. ITA tariff cuts will be fully implemented in 2004.

${ }^{17}$ This share reflects product coverage under the WTO Agreement on Agriculture; that is, HS Chapters 1 to 24 (excluding fish and fish products) and certain agricultural raw materials or semi-manufactures. Unbound items involve rice and rice products and several fish items.

${ }^{18}$ Unbound items cover: some fisheries products, wood, petroleum, chemicals (medicaments), apparel, fabricated metals (ball bearings), machinery (gas turbines, electric motors and generators, refrigeration equipment, data processing units, etc.), electronics products (radio and television receivers, capacitors, resistors), motor vehicles, maritime vessels and photographic equipment.

${ }^{19}$ The ITA, which was agreed at the Singapore Ministerial Conference and has 31 participants (1999), provides for the elimination of customs duties and other duties and charges on computers, telecom equipment, semiconductors, semiconductor manufacturing equipment, software, and scientific instruments, on an MFN basis; the phase-in of tariff reductions was set in four equal cuts (25\% each time) starting in July 1997 . The ITA does not cover consumer electronic goods. In 1995, Korea was the world's 5th leading exporter and 8th leading importer in IT goods. 
In 2000 , only $6.7 \%$ of Korea's tariff lines were duty-free, albeit more than three times as many as in 1996 (Table 1 and Chart 1). This proportion is expected to rise further to $13.3 \%$ once the Uruguay Round and ITA commitments are fully implemented. Full implementation of the ITA will remove duties on more than $13 \%$ of tariff lines, a significant increase compared to 1996.

(c) Specific and alternate duties

Specific and alternate duties currently account for only $0.5 \%$ of all tariff lines, the same as in 1996. The use of such duties, which can conceal high ad valorem equivalents (AVEs) and be more distorting than ad valorem tariffs, is therefore low compared to other major traders, notable the "Quad"; such duties apply to $6.9 \%$ of tariff lines in the case of Japan (see Annex). ${ }^{20}$ Whereas specific duties are applied to 21 tariff lines (cinematographic films and recorded tapes), alternate duties cover 28 agricultural items and 5 silk-related lines. While the specific duties have remained unchanged, the ad valorem component of the alternate duties has been reduced; in 2000, they ranged from $53.3 \%$ (silk worm cocoons) to $658 \%$ (sesamum seeds and oil). In 1999, ad valorem equivalents (AVEs) for specific duties on 13 items ranged from zero to $16.3 \%{ }^{21}$

(d) Tariff quotas

\section{Agricultural tariff quotas}

As a result of the "tariffication" of quantitative restrictions on imports of agricultural products, under Uruguay Round market-access commitments in agriculture, Korea has since 1995 applied tariff quotas to several product groups (including certain livestock items, fruit, vegetables, cereals, grains, tea, seeds, starches and food preparations), and has confined import quotas ${ }^{22}$ to two product categories, beef (until 2001), rice and rice products. All in-quota tariffs are ad valorem, while $18.1 \%$ of the outof-quota duties are alternate duties. The simple average in-quota MFN tariff rate is estimated at $18.4 \%$; while the corresponding average out-of-quota MFN tariff is $348.3 \%$ (ad valorem components only). ${ }^{23}$

\footnotetext{
${ }^{20}$ In the case of the U.S. and EU, the corresponding percentages are nearly $13 \%$ and $10 \%$, respectively.

${ }^{21}$ These AVEs were computed as collected duty rates; as explained earlier collected duty rates tend to underestimate the true AVEs.

${ }^{22}$ Accordingly, restraints on imports of 37 items were eliminated on 1 July 1997. Since then, most of these items have been subject only to a tariff; 6 items are subject to tariff quotas with high "out-of-quota" rates.

${ }^{23}$ Administration of tariff quotas is delegated to agricultural associations or state-trading agencies that may impose a mark-up on sales for certain items in addition to the "in-quota" tariff rate.
} 
In accordance with Article 5 of the WTO Agreement on Agriculture, products subject to tariff quotas may also be subject to special safeguard provisions. ${ }^{24}$ Under these provisions, a safeguard allowing for an additional duty of up to a third of the level of the applied tariff may be applied.

\section{"Autonomous" tariff quotas}

In addition to WTO-related agricultural tariff quotas, Korea has continued to grant concessional access through "autonomous" tariff quotas, usually for raw materials, inputs, semi-processed goods, components, parts and engines (61 four-digit HS items in 2000). The purpose of these measures is apparently to stabilise the domestic prices of such items. Under the Korean Customs Act, the in-quota rate may be $40 \%$ above or below the basic/general rate, while the out-of-quota rate may be $40 \%$ above the basic/general rate. As of July 1999, all in-quota rates have been below the basic/general rate.

(e) Level of MFN tariff protection

Between 1996 and 2000, the simple average applied MFN tariff rate fell from 14.4\% to $13.8 \%$. The OECD trade-weighted average also dropped slightly, from $10.9 \%$ to $10.6 \%$. However, during the same period, tariff protection for certain food items, canned fruit and vegetables, oils and fats, sugar, textiles and electrical appliances and houseware increased. The applied MFN tariff average for agricultural products is $50.3 \%$ (2000), more than seven times the average for industrial products (7.5\%). This level of tariff protection for agricultural products is to some extent due to "tariffication" under the Uruguay Round, which eliminated agricultural NTBs. The simple average is expected to fall to $12.7 \%$ once the Uruguay Round tariff cuts for both agricultural and industrial (including ITA items) products are fully implemented. ${ }^{25}$

The substantial gap between applied and bound rates - the simple averages are $13.8 \%$ versus $20.1 \%$ imparts an element of uncertainty to Korea's tariff. This gap has declined since 1996, however, mainly as a consequence of the substantial fall in bound rates. The difference between average applied and bound rates in 2000 was much higher for industrial products than for agricultural products (Charts 2 and 3). Applied MFN tariff rates for several (mostly manufactured) items will have to come down as they currently exceed the bound rates that will obtain once the Uruguay Round is fully implemented.

\footnotetext{
${ }^{24}$ Korea has used such provisions against certain beans, buckwheat, ground nuts, wheat starch, and sweet potato starch.

${ }^{25}$ Tariff indicators reflecting full implementation of the Uruguay Round and ITA are based solely on bound rates because one cannot be certain about future applied rates (except to assume that they should not exceed bound rates).
} 
Interestingly, the average rate of customs duty collected on total imports (the collected tariff rate) was only $2.9 \%$ in 1998 . This is not only considerably lower than the rate of $4.4 \%$ in 1996 , but also less than one-quarter of the average applied MFN rate. ${ }^{26}$ The large and growing gap between the average applied MFN rate and the collected duty rate can be explained, inter alia, by reduced in-quota rates under tariff quotas, the non-importation of items subject to prohibitive duties, duty concessions/exemptions and, to a lesser extent, by trade preferences, which mitigate the burden of tariffs on certain items and on imports of products from certain countries.

MFN tariff dispersion

The potential efficiency losses associated with the customs tariff depend not just on the average applied MFN tariff rates, but also on the dispersion of those rates across products. The higher the dispersion in tariff rates, particularly within groups of similar and, thus, highly substitutable products, the greater the likelihood that consumers' and producers' decisions are distorted by the tariff structure. ${ }^{27}$ The dispersion also provides an indication of the complexity of the tariff schedule. ${ }^{28}$ Judging from the four summary indicators (9-12) of tariff dispersion reported in Table 1 as well as in Chart 3, the dispersion in applied MFN tariff rates has hardly changed since 1996 despite the high compression of 6,800 tariff lines under the $8 \%$ duty rate in 1997. In 2000, imports of five 10-digit HS96 items (involving manioc) bear the highest ad valorem tariff of 926.8\%, nine items (certain cereals and inulin) are subject to the second highest rate of $835.9 \%$ and sorghum for seed is levied at the third highest rate of $814 \%$; about 84 items (agricultural, food, and chemicals) are subject to rates ranging from $105 \%$ to $787.8 \%$.

Judging by the coefficient of variation (CV), the dispersion in Korean tariffs has been slightly reduced from 4 in 1996 to 3.9 in 2000; however, it is expected to rise to 4.1 once the Uruguay Round and ITA undertakings are fully implemented. (The standard deviation (SD) shows a steady declining trend.) The percentages of tariffs involving domestic and international tariff "spikes" show a similar trend; a complete distribution of MFN tariff rates is depicted in Charts 3 and 4. Tariff spikes affect mainly the same broad product categories whose average tariffs are the highest; clearly, their elimination would further reduce the dispersion in tariff rates. The lower the dispersion in tariff rates, the less the potential distortion in the allocation of domestic resources caused by tariffs.

${ }^{26}$ An explanation may be that in 1998, when imports contracted, items subject to high duties (i.e. prohibitive rates) were not imported.

${ }^{27}$ Strictly speaking, a uniform nominal tariff minimizes the net welfare cost of such protection only if import demand elasticities are uniform across commodities and cross-price effects are negligible. Tariff uniformity may be desirable on administrative simplicity and political grounds, however. For a discussion of these and related matters, see Panagariya and Rodrik (1993).

${ }^{28}$ Moreover, the larger the dispersion in tariff rates applicable to various products, the greater the incentive for exporters and importers to reclassify products so that they are subject to lower tariffs. 
Tariff escalation means that the level of effective tariff protection increases as goods undergo further processing. It thus tends to promote primary and semi-finished goods, thereby possibly slowing the move to higher value-added production in developing countries. Minor changes in the customs tariff have resulted in little change in the pattern of tariff escalation. Notable exceptions involved the textiles and leather industries that benefited from more pronounced escalation. Higher tariff protection persists for semi-manufactures compared to finished items of the food, beverages and tobacco, paper printing and publishing, fabricated metal products and machinery industries (Chart 4); for these industries, the domestic production of raw materials and inputs receives more protection than subsequent production stages.

"Flexible" tariffs

Korea has maintained legislative provisions allowing for the application of temporarily higher duties, measures termed "flexible" tariffs, within the limit of WTO bindings. In addition to autonomous tariff quotas, these measures include adjustment duties, special emergency duties and seasonal duties.

Adjustment duties have been applied with a view, inter alia, to strengthening "temporarily" border protection for less-competitive domestic goods, or counteracting the impact of increased imports of items competing with vulnerable domestic items (e.g. agricultural, forest, livestock and marine products). After reaching a peak of 80 items in 1997, product coverage (mainly fish, rice, sugar, wood and textile articles, bicycles, toys) has gradually declined to 28 items in 2000; ad valorem rates have ranged from 1.3 to 10 times the item's general tariff level, and peaked at $100 \%$ (certain fish) in 1998.

A seasonal customs duty may be charged for goods whose price varies depending on the season with a view to protecting the domestic market and industry against imports of the same, similar or substitute goods; this duty may be either a higher rate than the basic rate (with the higher rate being equivalent to the difference between domestic and foreign prices), or a lower rate (equivalent to $40 \%$ of the basic duty). No such duties are currently in force.

\section{(i) Tariff preferences}

Korea grants limited preferential tariff treatment to developing countries under the Global System of Trade Preferences ${ }^{29}$, Trade Negotiations among Developing Countries and the Bangkok Agreement (encompassing Bangladesh, India, Laos, and Sri Lanka). Furthermore, as of January 2000, it grants 
unilateral concessions to imports of 80 commodities $^{30}$ from 48 least developed countries, permitting reductions of between $7.5 \%$ and $100 \%$ in the MFN rate.

Preferential tariff treatment may expand in the coming years. Although Korea has traditionally eschewed regional or bilateral trading arrangements, it is currently negotiating a free trade agreement with Chile. Moreover, it is considering the possibility of similar agreements with Japan and Thailand. In view of the fact that the average level of MFN tariff protection in Japan is less than half the level of Korea (see Annex), Japan probably has more to gain from such an agreement than Korea. As free trade agreements between Korea and Japan should cover substantially all trade in order to be consistent with the WTO rules, there would also be the thorny issue of how agriculture would be handled.

(j) Customs clearance procedures

Customs clearance requirements have been eased mainly through immediate release and paperless import clearance systems. Computerised customs clearance for imports (and exports) is now in operation.

\section{Non-Tariff Barriers to Trade}

Korea's non-tariff barriers (NTBs) to trade currently involve, inter alia, import prohibitions, quantitative restrictions, tax measures, state-trading operations (mainly in agriculture and livestock), discriminatory government procurement practices and standards requirements. In addition, Korea, like other WTO Members, has several types of contingency measures at its disposal, namely countervailing and anti-dumping duties as well as safeguards. These measures are designed to counteract "unfair" trade practices, such as export subsidies and the dumping of products onto the Korean market. The Government's toleration of anti-competitive practices by large domestic conglomerates (chaebols) and state-owned enterprises may also constitute a barrier to trade. Furthermore, frugality campaigns (although they have officially ceased) and a deeply-rooted traditional ("Buy Korean") consumption pattern constitute significant impediments to imports.

(a) Import prohibitions

Korea replaced a "positive" list with a "negative" list of import (export) approval requirements in 1997. The importation of certain goods may be prohibited or restricted for the protection of public morals, human health, hygiene and sanitation, animal and plant life, environmental conservation or

\footnotetext{
${ }^{29}$ They mainly cover unprocessed agricultural and livestock items, chemicals, bovine leather, woven fabrics and metallic inputs.

${ }^{30}$ These include 26 agricultural and fish products, 13 forestry items and 42 industrial raw materials.
} 
essential security interests in compliance with domestic legislation requirements or international commitments. For example, since June 1999 the importation, sale and use of pork possibly containing cancer-causing dioxin from Belgium, France, and the Netherlands, as well as chicken, beef, dairy and related food products from Belgium, has been prohibited until safety is ensured. The scope of import prohibitions/approval affecting used goods, an old means of helping develop domestic capital goods industry, has been reduced. By 1999, imports subject to certification, permission or type approval covered 1,074 ten-digit HS items or $9.7 \%$ of total tariff lines.

Prohibitions on commercial grounds have been eliminated with the suppression of those on sensitive items from Japan (Import Diversification System) on 30 June 1999 (six months ahead of schedule) as well as those on fish (length-based restriction, seasonal import ban); the scope of import prohibitions affecting used goods has also been reduced.

(b) Quantitative restrictions

At present, quantitative restrictions affect only beef (until 2001) and rice; no industrial items are subject to such restrictions.

(c) Contingent protection

Compared to other WTO Members of similar size, Korea has made little use of contingent protection in the form of anti-dumping and countervailing measures and safeguards. After reaching a peak in 1996-97, anti-dumping actions have since declined. Of the 37 anti-dumping investigations initiated between 1996 and 2000 (March), 20 were subject to provisional measures (with reduced recourse to this action since 1997), 24 resulted in definitive measures (including five price undertakings/reductions) that were in force by September 1999. Most of the cases affected machinery and chemical items originating mainly from the EU, China, the United States and Japan. No countervailing actions have been taken since 1996. While very few products are subject to safeguards, the coverage of such measures has increased slightly (from five to seven items).

(d) Technical barriers to trade

In recognition of the fact that domestic standards (and technical regulations) also constitute potential barriers to trade, Korea has been aligning its domestic standards with relevant international standards whenever possible and feasible. Although Korea has been an ISO member since 1963, by 1999, about 500 of the 10,000 or so Korean Standards (KS) were identical to international standards (ISO, IEC), the same number as in 1996, while 2,000 KS were equivalent with minor deviations. Thus, about one-quarter of all KS currently in force are identical or roughly equivalent to international standards. 
(e) Taxation

In some instances, Korea has also structured its indirect tax regime in such a way as to afford protection equivalent to an import tariff. ${ }^{31}$ For example, its multi-tiered tax on the sale of alcoholic beverages consists of an ad valorem liquor tax, whose rates vary across various categories of distilled spirits. This tax is supplemented by a surtax on certain of these sales, determined as a percentage of the established liquor tax. Until recently, the outcome was that whiskies, brandies, rum, vodka, tequila, etc., were taxed considerable more than locally-produced alcoholic beverages, notably "soju", with which they competed directly. This resulted in a dispute between Korea and several of its trading partners (the United States, the EU, Canada, and Mexico). ${ }^{32}$ As a consequence of this ruling, the Korean Government has raised the tax rate on "soju" from 35\% to $75 \%$ as of 1 January 2000 so as to bring it into line with the rates levied on other (imported) alcoholic beverages.

As regards imported motor vehicles, not only have they been subject to frugality campaigns, but also their purchase is believed to have triggered tax audits. ${ }^{33}$ However, the authorities deny that tax audits have ever been conducted to dissuade taxpayers from purchasing imported cars; indeed, in May 1997, tax officials were instructed to refrain from any administrative action that might be interpreted as an attempt to discourage imports.

\section{Government procurement}

Government procurement practices may also discriminate against imports. Insofar as local suppliers are favoured over suppliers located abroad, by means of explicit price preference margins or discriminatory tendering, such practices can have effects equivalent to import tariffs as far as government purchases are concerned. These effects may be mitigated insofar as the private sector purchases the imported goods displaced by preferential government procurement practices.

In 1999 the total Korean government procurement market for goods, services and construction was estimated at around W 43.7 trillion (US\$43 billion). Procurement by entities covered by the WTO Agreement on Government Procurement (GPA) represented $77.2 \%$ of this market, which is dominated by construction contracts. Notwithstanding the GPA, which operates on a reciprocal basis and covers contracts by entities contained in the signatory's schedule of commitments, foreign suppliers captured less than $5 \%$ of the procurement market (mainly involving goods), with the United States and the EU accounting for the largest individual shares. This small share is partly due

\footnotetext{
${ }^{31}$ An excise tax levied on a good that is not produced domestically is equivalent to a tariff.

${ }^{32}$ In September 1998, the Dispute Settlement Body (DSB) of the WTO adopted the Panel Report, which found that such dissimilar taxation of like products violated Article III of the GATT 1994 and constituted protection to domestic production.

${ }^{33} \operatorname{USTR}(1999)$.
} 
to a shift from open to single tendering and a policy favouring domestic small and medium-sized enterprises (SMEs), particularly in provincial towns; indeed, the share of SMEs in the government procurement market has grown from $30 \%$ to $57 \%$ since $1997 .{ }^{34}$ In areas not covered by the GPA, the Government tends to favour domestic suppliers of goods and services (as in the case of the construction of the new Inchon International Airport, for example).

(g) State-owned enterprises

Despite a fifth round of privatisation launched in 1998, the State still participates in a wide-range of trade and/or trade-related activities. Between 1997 and the end of 1999, the number of non-financial state-owned enterprises (including government enterprises, government-invested enterprises and their subsidiaries) was reduced from 108 to 91 . In addition to these enterprises owned and controlled by the Central Government, there are about 200 so-called "grey area" public enterprises with managerial and operational ties to the Government; another 298 enterprises are owned and controlled by local authorities.

Several state entities and producers associations are involved directly in agricultural, livestock and forestry trade; these entities allocate and/or operate tariff quotas and quantitative restrictions in the context of Korea's WTO commitments in agriculture. Moreover, as most public enterprises benefit from monopoly status or from exclusive rights stipulated in laws and regulations, these firms may discriminate against and restrict access to foreign supplies and thereby distort competition. This appears to have been the case as regards several major enterprises (including Korea Telecom, Korea Electric Power Corporation, Korea Gas Corporation, Korea Heavy Industries \& Construction, Korea Tobacco \& Ginseng Corporation and Pohang Iron and Steel Company).

(h) Frugality campaigns

In the face of 1996 balance-of-payments difficulties, the financial crisis and the subsequent IMF stabilisation package, frugality campaigns have been directed at individual consumption of imported "luxury goods" (e.g. motor vehicles, sports equipment cosmetics, fashion items, home appliances, beef, cigarettes, whiskey) and foreign travel. While these campaigns have been suspended in recent years, foreign business interests remain the targets of domestic non-governmental groups; the Government has officially denied that it is involved in these campaigns ${ }^{35}$ and efforts have been made

34 The Korea Herald [Online], 18 January 1997. Available at: http://www.koreaherald.co.kr/ [30 September 1999].

${ }^{35}$ Previously the Government urged Koreans to "restrain themselves from a trend of extravagance, wastefulness and indiscriminate foreign travel" (President Kim's speech, 2 July 1996) (European Commission (1999)). 
to promote a better understanding of the benefits of freer trade and fair competition. ${ }^{36}$ Nonetheless, widespread economic nationalism seems to persist and "luxury goods" tend to have a negative connotation to Korean consumers; for example, in autumn 1999 a poll revealed that $60 \%$ of interviewed persons considered the purchase of a foreign car detrimental to Korea. ${ }^{37}$ The combination of this nationalistic consumption pattern (also found in other countries) and product marketing difficulties (e.g. regarding the establishment of distribution and after sales network) may constitute considerable non-quantifiable and non-negotiable barriers to imports.

\section{(i) Anti-competitive private practices}

Trade and domestic resource allocation may also be distorted by anti-competitive private practices and, by extension, any failure by the Government to take appropriate action against them by means of competition policy.

The chaebols have posed a significant concern for foreign competitors (e.g. pressure by the chaebols on SMEs not to supply foreign-enterprises, restrained access to distribution channels, and the chaebols dominant access to domestic credit) in the Korean market. In line with regulatory reform in this area, since 1998 the Korea Fair Trade Commission (KFTC) has conducted probes on unfair/illegal intra-group transactions with a view to dealing with cross-subsidization among chaebol-affiliates and creating competition within the group; by September 1999, the KFTC planned to launch a third probe into alleged illegal internal trading at affiliates of five or six large conglomerates ranked outside the top five (Hyundai, Daewoo, Samsung, LG and SK).

Since 1996, efforts to monitor abuse of dominant market power by public enterprises and enforce legislation have been undertaken. According to recent KFTC investigations, several public entities were involved in illegal trade practices among subsidiaries (Korea Land Corp., Korea Water Resources Corp., Korea Petroleum Development Corp., Agricultural and Fishery Marketing Corp., and Korea National Tourism Organisation) as well as in imposing contract clauses unfavourable to clients and suppliers (Daehan Coal Corp. Korea Mining Promotion Corp., Rural Development Corp., Korea Trade-Investment Promotion Agency, Securities Printing, and Minting Corp.). Furthermore, certain state-owned firms (e.g. Korea Electric Power Corp.) are involved in mandatory cross-subsidisation and have invested in other sectors (outside their core-business), both at home and abroad.

\footnotetext{
${ }^{36}$ In recent years, President Kim Dae-jung has emphasised repeatedly at televised town hall meetings that consumers should choose best quality goods at best available prices regardless of origin (statement of Ambassador Chung Eui-yong, Deputy Minister for Trade, Ministry of Foreign Affairs and Trade at the meeting of the WTO Trade Policy Review Body on Korea (26 September 2000)).

${ }^{37}$ USTR (2000).
} 
Although the post-crisis structural reforms have expanded the scope for competition, given the short period that has elapsed since their introduction, and the wide, complex and interdependent links between major domestic economic agents, the full impact of major structural reforms has yet to be felt; both the chaebols and state-owned enterprises with cross-sectoral and overseas presence still appear to be virtually untouched by reforms.

\section{Other NTBs}

Border measures may be reinforced or replaced by less transparent internal measures with similar import restricting effects, as in the case of beef or pharmaceuticals, for example. Imports of beef are already subject to quantitative restrictions. In addition, under Korea's current retail sales system, imported beef may be sold only in officially designated stores (i.e. "imported beef" stores rather than "domestic beef" stores). While the authorities maintain that the system is aimed at fighting fraud (i.e. ensuring that cheap foreign meat is not sold as domestic meat) and does not affect trade in beef, it may nonetheless impede the sale of imported beef. Interestingly, between 1996 and 1998, the number of the "imported beef" stores declined from 7,569 to 5,498. Furthermore, while beef imports are to be liberalised (so that there will no longer be government involvement in the beef trade) as of January 2001, at the same time, a further measure differentiating imported beef from domestic beef will be applied. As of August 1999 a new pharmaceuticals policy has, inter alia, allowed for imported products to be listed on the national reimbursement schedule, thus reducing the scope of non-tariff barriers to foreign medicines.

\section{CONCLUDING REMARKS}

The foregoing discussion of tariffs and non-tariff barriers to trade (NTBs) in Korea highlights several key features of its present trade regime. First and foremost, the customs tariff remains the main instrument of Korea's trade policy. Compared to other major industrialised countries, it accords a high average level of protection - the average applied MFN tariff is currently nearly $14 \%$. It also contains a considerable number of tariff "spikes", particularly as far as agricultural products are concerned, largely as a result of the "tariffication" exercise. At the same time, the tariff embodies a certain degree of escalation. Consequently, the customs tariff is a potentially serious distortion to competition and thus an obstacle to the efficient allocation of domestic resources. With its multiplicity of rates, it is also a highly complex instrument, although its complexity has been reduced by virtue of tariff reductions on industrial items in 1997, which mean that nearly two-thirds of all tariff lines are now subject to a rate of $8 \%$ rate. Moreover, applied tariff rates currently fall short of bound rates by an average of 6.3 percentage points. The consequent, albeit declining, gap between bound and applied rates provides considerable scope for the authorities to raise applied MFN tariff, 
either by increasing general rates or by occasionally levying "flexible" tariffs, thereby imparting a considerable degree of uncertainty to the applied tariff. Furthermore, so-called "autonomous" tariff quotas (mainly for raw materials and inputs) are used in addition to WTO-related agricultural tariff quotas.

As regards NTBs, those concerning agricultural items persist. However, the scope of NTBs affecting industrial products has been considerably reduced, particularly those involving prohibitions, contingency measures, potentially discriminatory standards and government procurement practices. Action in the context of structural reforms and enforcement of fair competition rules has also been taken so as reduce barriers to trade arising from the operations of state-owned firms and the large domestic business conglomerates (chaebols).

Finally, one should bear in mind that the tariffs and NTBs discussed in this paper pertain largely to border measures. In order to draw firm conclusions regarding Korea's overall trade regime, one obviously needs to take into account not just border measures, but also internal government actions that distort trade and resource allocation. Such actions include other forms of government assistance, notably the wide use of tax concessions and soft loans, as well as remaining restraints on foreign investment in a number of areas. ${ }^{38}$

\section{Acknowledgements}

The authors are indebted to Verena Hess, for her statistical assistance in computing the tariff indicators reported in this paper. The opinions expressed are solely those of the authors and, as such, should not be attributed to the WTO Secretariat.

\footnotetext{
${ }^{38}$ The sectors subject to these restraints in 2000 were: cattle raising; meat wholesale; growing of rice and barley; inshore and coastal fishing; public power generation; domestic banking other than commercial banking; news agency activities; publishing of newspapers and publishing periodicals; coastal water passenger and passenger transportation; non-scheduled air transportation; wire telegraph and telephone wireless telegraph and telephone telecommunications; radio and television broadcasting; and, cable broadcasting.
} 


\section{References}

European Commission (1999), Market Access Sectoral and Trade Barriers Database [Online]. Available at: http://mkaccdb.eu.int/mkdb/chksel.pl [14 September 1999].

Panagariya, A. and D. Rodrik (1993), Political Economy Arguments for a Uniform Tariff, International Economic Review 34(3), 685-703.

USTR (1999), 1999 National Trade Estimate on Foreign Trade Barriers [Online], Washington, D.C. Available at: http://www.ustr.gov/reports/nte/1999/contents.html (as of 14 September 1999).

USTR (2000), 2000 National Trade Estimate on Foreign Trade Barriers [Online], Washington, D.C. Available at: http://www.ustr.gov/reports/nte/2000/contents.html (as of 14 June 2000). 
Table 1

Structure of applied MFN tariffs in Korea

(Per cent)

\begin{tabular}{|c|c|c|c|c|}
\hline \multicolumn{2}{|c|}{ Indicators } & \multirow{2}{*}{$\begin{array}{c}1996 \\
90.4\end{array}$} & \multirow{2}{*}{$\begin{array}{c}\begin{array}{c}\mathbf{2 0 0 0} \\
\text { (including ITA) }\end{array} \\
91.7\end{array}$} & \multirow{2}{*}{$\begin{array}{c}\begin{array}{c}\text { Fully implemented } \\
\text { U.R. results } \\
\text { (including ITA) }^{\mathbf{a}}\end{array} \\
91.7\end{array}$} \\
\hline 1. & Bound tariff lines (per cent of all tariff lines) & & & \\
\hline 2. & Duty-free tariff lines (per cent of all tariff lines) & 2.0 & 6.7 & 13.3 \\
\hline 3. & Specific and alternate tariffs (per cent of all tariff lines) & 0.5 & 0.5 & 0.5 \\
\hline \multirow[t]{3}{*}{4.} & Tariff quota & & & \\
\hline & $\begin{array}{l}\text { (a) Autonomous tariff quotas (per cent of all tariff } \\
\text { lines) }\end{array}$ & 0.6 & 0.5 & .. \\
\hline & $\begin{array}{l}\text { (b) Agricultural tariff quotas }{ }^{\mathrm{b}} \text { (per cent of all } \\
\text { tariff lines) }\end{array}$ & 1.7 & 1.5 & 1.5 \\
\hline 5. & Tariffs with no ad valorem equivalent & 0.5 & 0.5 & 0.5 \\
\hline 6. & Simple average bound tariff rate & 27.6 & 20.1 & 16.9 \\
\hline \multirow[t]{3}{*}{7.} & Simple average applied tariff rate & 14.4 & 13.8 & 12.7 \\
\hline & Agricultural products (HS $01-24)^{\mathrm{c}}$ & 51.8 & 50.3 & 47.9 \\
\hline & Industrial Products (HS 25-97) & 7.7 & 7.5 & 6.6 \\
\hline 8. & Import-weighted ${ }^{\mathrm{d}}$ average tariff rate & 10.9 & $10.6^{\mathrm{e}}$ & .. \\
\hline 9. & Domestic tariff "spikes" ${ }^{\mathrm{f}}$ & 2.4 & 2.2 & 2.5 \\
\hline 10. & International tariff "spikes"g & 8.7 & 8.6 & 8.7 \\
\hline & Overall standard deviation (SD) of tariff rates & 57.2 & 54.4 & 52.2 \\
\hline & Coefficient of variation $(\mathrm{CV})$ of tariff rates & 4.0 & 3.9 & 4.1 \\
\hline
\end{tabular}

Not available.

Using 2000 nomenclature.

According to the definition of agricultural products used in the WTO Agreement on Agriculture.

Under the definition, as used in the WTO Agreement on Agriculture, the simple applied tariff average on Agricultural imports is

$54.8 \%$ in 2000 .

Constant (1998) OECD import weight.

Average for 1999

Domestic tariff "spikes" are defined as those rates exceeding three times the overall simple average applied MFN rate.

International tariff "spikes" are defined as those exceeding $15 \%$.

Note: Calculations exclude in-quota rates and include out-of-quota rates and take into account the ad valorem part of mixed rates.

Source: WTO Secretariat estimates. 
Annex

Structure of applied MFN tariffs in Japan

(Per cent)

\begin{tabular}{|c|c|c|c|c|}
\hline & Indicators & FY1998 ${ }^{\mathrm{a}}$ & FY2000 & U.R. ${ }^{\mathrm{c}}$ \\
\hline 1. & Bound tariff lines (per cent of all tariff lines) & 98.9 & 98.9 & 98.9 \\
\hline 2. & Duty free tariff lines (per cent of tariff lines) & 37.7 & 37.1 & 41.2 \\
\hline \multirow[t]{2}{*}{3.} & Non-ad valorem tariffs (per cent of all tariff lines) & 6.8 & 6.9 & 6.3 \\
\hline & Of which differential and sliding duties (per cent of all tariff lines) & 0.3 & 0.4 & 0.0 \\
\hline 4. & Tariff quotas (per cent of all tariff lines) & 2.0 & 2.0 & 2.0 \\
\hline \multirow[t]{2}{*}{5.} & $\begin{array}{l}\text { Non-ad valorem tariffs with no ad valorem equivalent (per cent of all } \\
\text { tariff lines) }\end{array}$ & 6.8 & 2.0 & 1.9 \\
\hline & Excluding "in-quota" rates & 6.9 & 2.1 & 1.8 \\
\hline 6. & Simple average bound tariff rate & 5.6 & 6.6 & 6.3 \\
\hline \multirow[t]{3}{*}{7.} & Simple average applied tariff rate & 5.4 & 6.5 & 6.3 \\
\hline & Agricultural products (HS 01-24) ${ }^{\mathrm{d}}$ & 11.8 & 17.0 & 17.4 \\
\hline & Industrial products (HS 25-97) & 3.9 & 3.9 & 3.6 \\
\hline 8. & Import-weighted average applied tariff rate & .. & .. & .. \\
\hline 9. & Domestic tariff "spikes"e & 6.8 & 5.9 & 6.0 \\
\hline 10. & International tariff "spikes" ${ }^{\mathrm{f}}$ & 7.4 & 7.1 & 6.9 \\
\hline 11. & Overall standard deviation (SD) of tariff rates & 7.4 & 24.8 & 25.0 \\
\hline 12. & Coefficient of variation $(\mathrm{CV})$ of tariff rates & 1.4 & 3.8 & 4.0 \\
\hline
\end{tabular}

.. Not available.

a Not including AVEs, but taking into account the ad valorem part of compound and alternate rates.

b Using 1999 AVEs, as available, provided by the Japanese authorities.

c Using 2000 nomenclature.

d Under the definition used in the WTO Agreement on Agriculture the simple applied tariff average on agricultural imports is $18.2 \%$ in FY2000.

e Domestic tariff "spikes" are defined as those exceeding three times the overall simple average applied rate (indicator 7); thus, in 2000 , for example, a domestic tariff spike is defined as one that exceeds $19.5 \%$ (that is, three times the average applied rate of $6.5 \%)$.

f International tariff "spikes" are defined as those exceeding $15 \%$.

Note: Indicators 1, 3 and 4 are calculated taking into account all tariff lines (i.e. in-quota and out-of-quota tariff lines). Each of the other ten indicators exclude in-quota lines.

Source: WTO Secretariat estimates. 


\section{Chart 1}

\section{Distribution of MFN tariff rates, 1996 and 2000}

Number of tariff lines

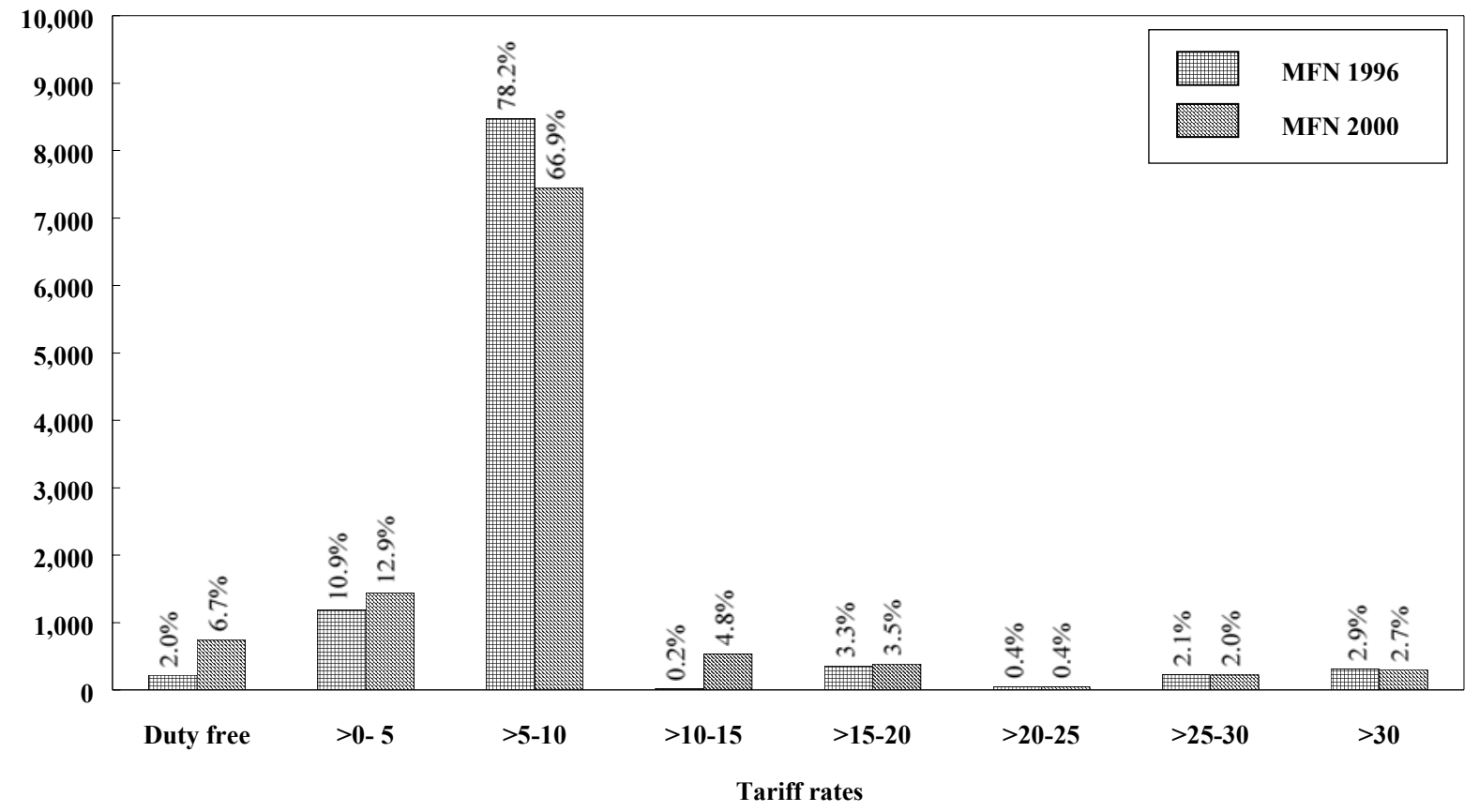

Note: Calculations exclude specific duties and include the ad valorem component of mixed rates. 


\section{Chart 2}

\section{Applied and bound tariffs on agricultural products. 2000 and 2004}

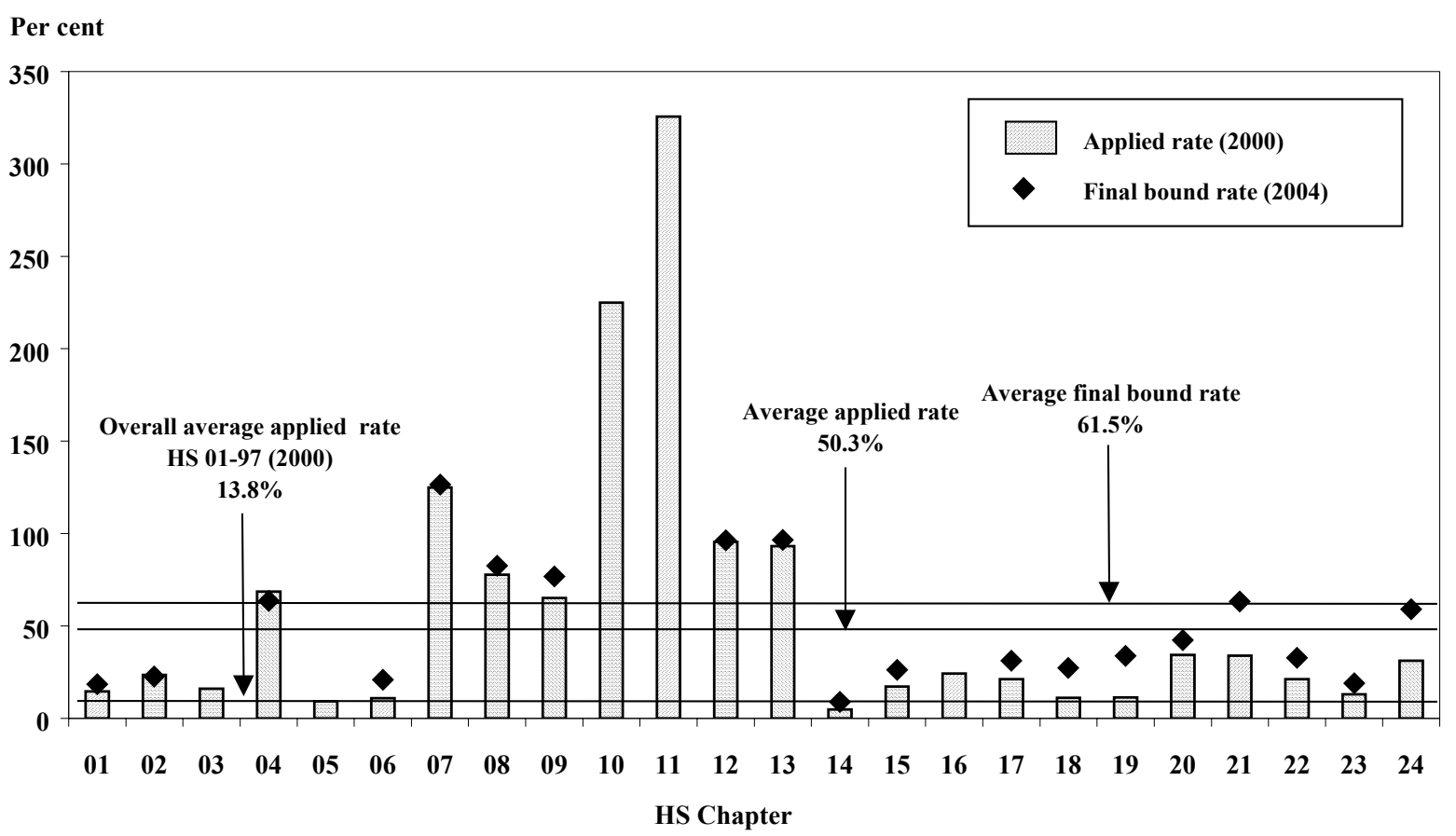

\section{HS Chapter Description}

HS Chapter

$\begin{array}{ll}01 & \text { Live animals } \\ 02 & \text { Meat and edible meat offals } \\ 03 & \text { Fish and crustaceans, molluscs and other aquatic invertebrates } \\ 04 & \text { Dairy produce, birds eggs, natural honey, edible products of animal origin } \\ 05 & \text { Products of animal origin, n.e.s. } \\ 06 & \text { Live trees and other plants; bulbs, roots and the like; cut flowers } \\ 07 & \text { Edible vegetables and certain roots and tubers } \\ 08 & \text { Edible fruit and nuts; peel of citrus fruits or melons } \\ 09 & \text { Coffee, tea, mate and spices } \\ 10 & \text { Cereals } \\ 11 & \text { Products of the milling industry; malt; starches; wheat gluten } \\ 12 & \text { Oil seeds and oleaginous fruits; miscellaneous grains, seeds and fruit } \\ 13 & \text { Lacs; gums, resins and other vegetable saps and extracts } \\ 14 & \text { Vegetable plaiting materials; vegetable products n.e.s. } \\ 15 & \text { Animal or vegetable fats and oils and other cleavage products; prepared edible fats; etc. } \\ 16 & \text { Preparations of meat, or fish or of crustaceans, molluscs or other aquatic invertebrates } \\ 17 & \text { Sugars and sugar confectionery } \\ 18 & \text { Cocoa and cocoa preparations } \\ 19 & \text { Preparations of cereals, flour, starch or milk; pastrycooks' products } \\ 20 & \text { Preparations of vegetables, fruit, nuts or other parts of plants } \\ 21 & \text { Miscellaneous edible preparations } \\ 22 & \text { Beverages, spirits and vinegar } \\ 23 & \text { Residues and waste from the food industries; prepared animal fodder } \\ 24 & \text { Tobacco and manufactured tobacco substitutes }\end{array}$

Note: Calculations exclude specific duties and include the ad valorem part of mixed rates. The absence of entries for chapters $03,05,10,11$ and 16 is due to non-bindings. 


\section{Chart 3}

\section{Average tariff rates on manufactured products by HS chapter, 2000 and 2004}

\section{Per cent}

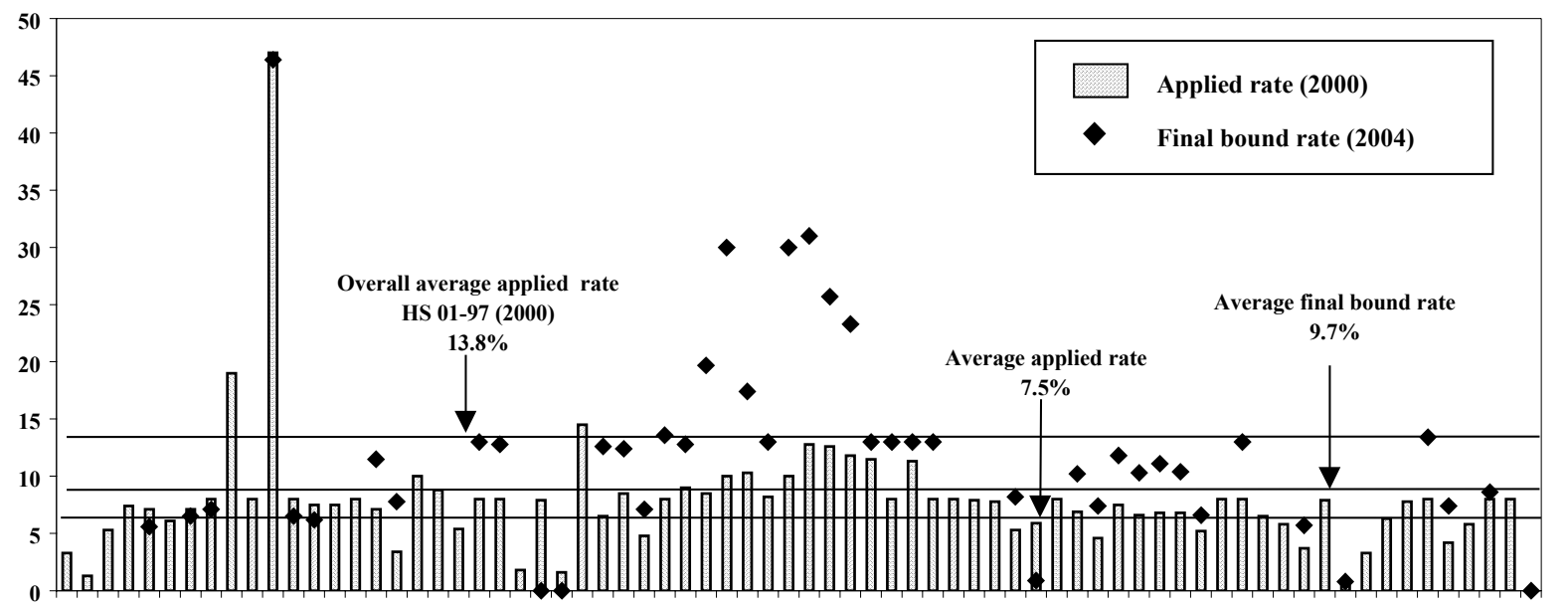

$\begin{array}{llllllllllllllllllllllllllllllllllll}25 & 27 & 29 & 31 & 33 & 35 & 37 & 39 & 41 & 43 & 45 & 47 & 49 & 51 & 53 & 55 & 57 & 59 & 61 & 63 & 65 & 67 & 69 & 71 & 73 & 75 & 78 & 80 & 82 & 84 & 86 & 88 & 90 & 92 & 94 & 96\end{array}$

$\begin{array}{llllllllllllllllllllllllllllllllllll}26 & 28 & 30 & 32 & 34 & 36 & 38 & 40 & 42 & 44 & 46 & 48 & 50 & 52 & 54 & 56 & 58 & 60 & 62 & 64 & 66 & 68 & 70 & 72 & 74 & 76 & 79 & 81 & 83 & 85 & 87 & 89 & 91 & 93 & 95 & 97\end{array}$

HS Description

25 Salt; sulphur; earths and stone, etc.

Ores, slag and ash

Mineral fuels, mineral oils, etc.

Inorganic chemicals; organic or

inorganic compounds of precious

metals, etc.

Organic chemcials

Pharmaceutical products

Fertilizers

Tanning or dyeing extracts etc.

Essential oils and resinoids;

perfumery, cosmetic or toilet preparations

34 Soap, organic surface-active

agents washing prep., etc.

Albuminoidal substances;

modified starches; glues, etc.

36 Explosives; pyrotechnic products;

matches, etc

37 Photographic or cinematographic goods

38 Miscellaneous chemical products

Plastics and articles thereof

Rubber and articles thereof

Raw hides and skins and leather

Articles of leather, etc.

Furskins and artifical fur;

manufactures thereof

Wood and articles of wood, etc.

Cork and articles of cork

Manuf. of straw, of esparto, etc.

Pulp of wood or of other

HS Chapter

\section{HS Description}

Chapter

48 Paper and paper board, etc.

49 Printed books, newspapers, etc.

50 Silk

51 Wool; fine or coarse animal

hair, etc.

52 Cotton

53 Other vegetable textile fibres

54 Man-made filaments

55 Man-made staple fibres

$56 \quad$ Wadding, felt and non-wovens; special yarns; twine, cordage, etc.

57 Carpets; other textile floor coverings

58 Special woven fabrics; lace, etc.

59 Impregnated, coated, covered or laminated textile fabrics, etc.

$60 \quad$ Knitted or crocheted fabrics

61 Articles of apparel and clothing accessories, knitted or crocheted

62 Articles of apparel and clothing accessories, not knitted, etc.

63 Other made-up textile articles; sets, worn clothing, etc.

Footwear, gaiters, etc.

Headgear and parts thereof

Umbrellas, walking-sticks, etc.

Prepared feathers and down, etc.

Articles of stone, plaster, etc.

Ceramic products

Glass and glassware

Natural or cultured pearls,

precious or semi-precious stones,

precious metals, etc.

\author{
HS Description \\ Chapter \\ 72 Iron and steel \\ 73 Articles of iron and steel \\ Copper and articles thereof \\ Nickel and articles thereof \\ Aluminium etc. \\ Lead and artilces thereof \\ Zinc and articles thereof \\ Tin and articles thereof \\ Other base metals, etc. \\ Tools, implements, cutler \\ spoons and forks, etc. \\ Misc. articles of base metals \\ Nuclear reactors, boilers, \\ machinery, etc. \\ Electrical machinery and \\ equipment, etc. \\ Railway or tramway \\ locomotives, etc. \\ $87 \quad$ Vehicles other than railway \\ or tramway rolling-stock; etc. \\ Aircraft, spacecraft, etc. \\ Ships, boats, etc. \\ Optical, photographic, etc. \\ apparatus \\ Clocks and watches, etc. \\ Musical instruments, etc. \\ Arms and ammunition, etc. \\ Furniture, bedding, etc. \\ Toy, games, etc. \\ Miscellaneous manuf. articles \\ Works of art, antiques, etc.
}

Note: Calculations exclude specific duties and include ad valorem parts of mixed rates and recent improvements in tariff binding commitments (i.e., automobiles, ITA items). The absence of entries for chapters $25,26,27,28,30,33,34,38,39,42,43,44,47,50$, $68,69,70,73,82,84,85,87,89,90,91,94$ and 97 is due to non-bindings. Some items are finally bound up to 2009. 


\section{Chart 4}

\section{Tariff escalation by 2-digit ISIC industry, 1996 and 2000}

\section{Per cent}

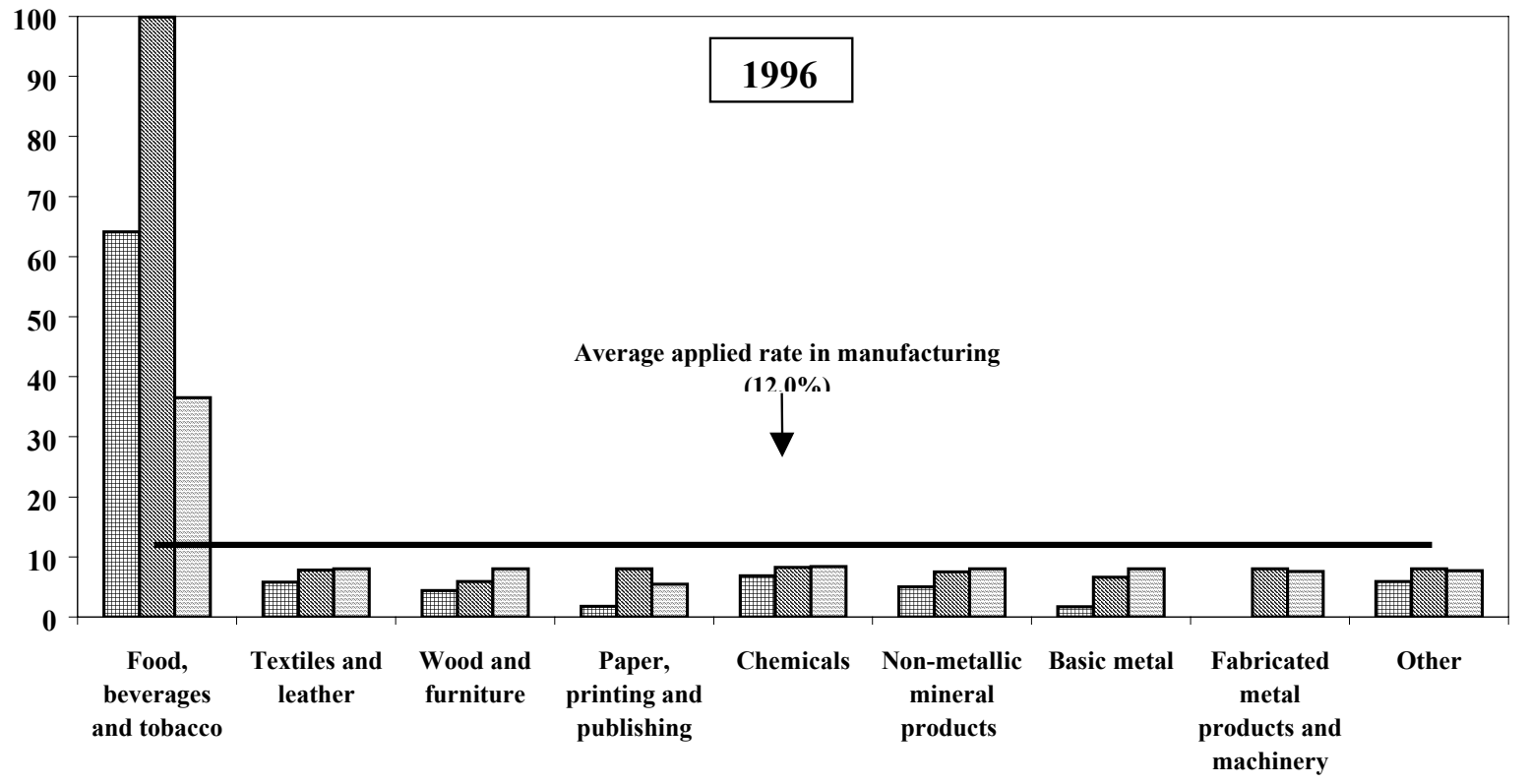

Per cent

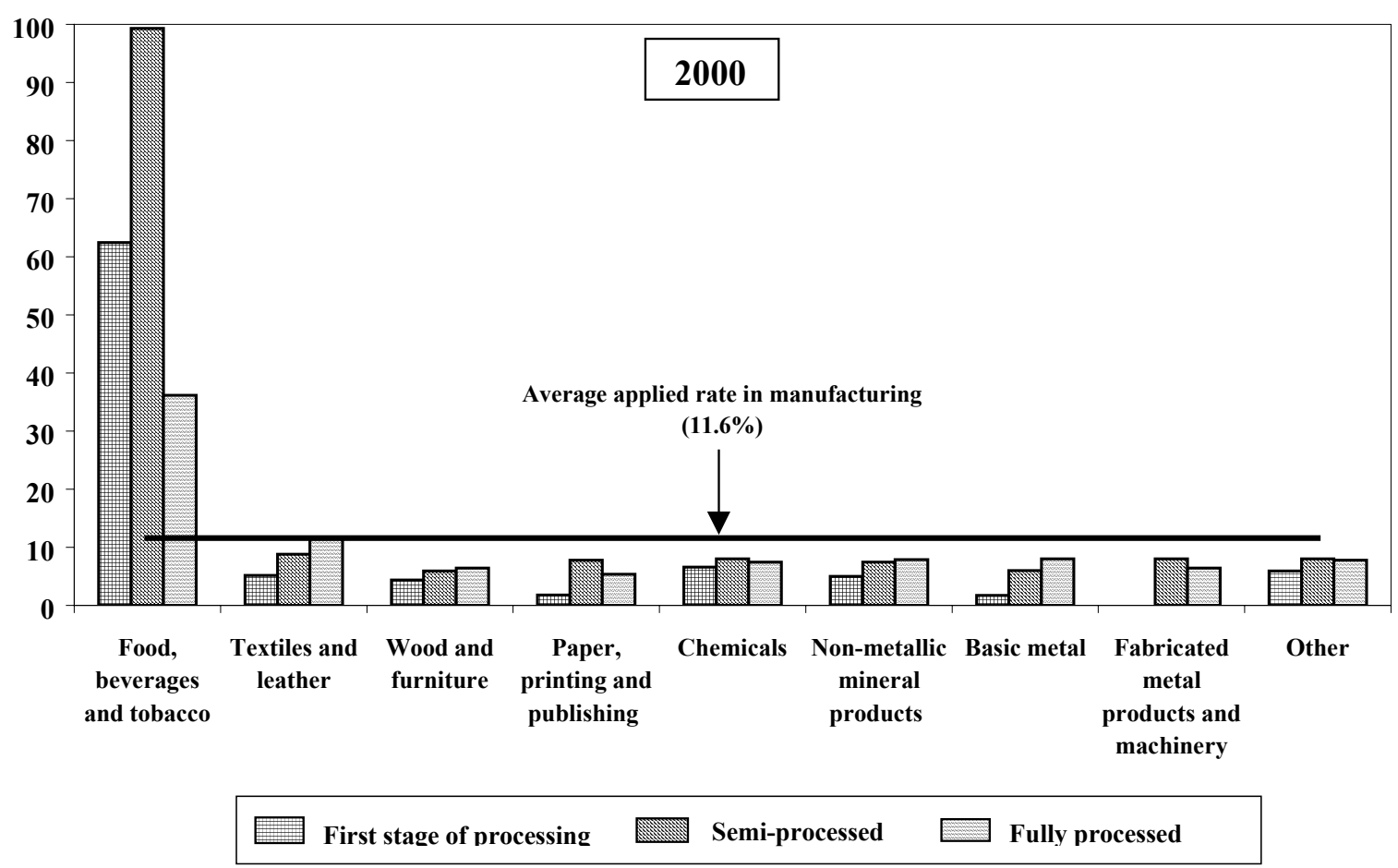

Note: Calculations exclude specific duties and include the ad valorem component of mixed rates. 